\title{
Embedding eWOM into efficiency DEA modelling: an application to the hospitality sector
}

Article

Accepted Version

Creative Commons: Attribution-Noncommercial-No Derivative Works 4.0

Mariani, M. M. and Visani, F. (2019) Embedding eWOM into efficiency DEA modelling: an application to the hospitality sector. International Journal of Hospitality Management, 80. pp. 1-12. ISSN 1873-4693 doi:

https://doi.org/10.1016/j.ijhm.2019.01.002 Available at https://centaur.reading.ac.uk/81465/

It is advisable to refer to the publisher's version if you intend to cite from the work. See Guidance on citing.

To link to this article DOI: http://dx.doi.org/10.1016/j.ijhm.2019.01.002

Publisher: Elsevier

All outputs in CentAUR are protected by Intellectual Property Rights law, including copyright law. Copyright and IPR is retained by the creators or other copyright holders. Terms and conditions for use of this material are defined in the End User Agreement.

www.reading.ac.uk/centaur

\section{CentAUR}


Central Archive at the University of Reading

Reading's research outputs online 


\title{
Embedding eWOM into efficiency DEA modelling: \\ An application to the hospitality sector
}

\begin{abstract}
This paper develops and tests an innovative DEA model in the hospitality sector, by originally embedding online customer ratings among the outputs of the model. Based on a sample of 268 independent hotels located in Rome (Italy), we test a eWOM-informed DEA model and find that the introduction of online ratings among the outputs of the model significantly affects the assessment of hotels' efficiency regardless of hotel category. The efficiency rankings generated by the DEA models embedding eWOM are radically different compared to those resulting from DEA models exclusively based on financial variables. The number of hotels improving their position in the efficiency rankings is lower than the number of hotels decreasing in the ranking. However, the average efficiency variation is positive and higher for 2- and 3- stars hotels than for 4- and 5- stars hotels. Implications for researchers in hospitality and tourism, managers and practitioners are discussed.
\end{abstract}

Keywords: eWOM, online reviews, DEA, hotel industry, performance, efficiency

Paper type: Research paper 


\section{Introduction}

Over the last twenty years the development of ICTs and online review platforms such as Tripadvisor and Online Travel Agencies (OTAs) such as Booking and Expedia have brought about an uncontrollable proliferation of travel-related user generated content in the form of online reviews (ORs). For instance, the number of ORs on TripAdvisor have increased from 1 million at the beginning of 2005 to more than 570 million in 2017 (TripAdvisor, 2018).

Overall, ORs have generated a consumer paradigm shift in the way travelers collect information before their trips (Gretzel \& Yoo, 2008), plan their journeys (Litvin, Goldsmith, \& Pan, 2008) and in how they eventually purchase travel and tourism products and services (Casaló et al., 2015) and review them (Wang \& Fesenmaier, 2004). This is particularly true in the contemporary hotel sector that besides facing the horizontal and vertical competition of sharing economy platforms (e.g., AirBnB) and online travel intermediaries (e.g., Booking.com) as well as independent online travel review websites (e.g., Tripadvisor), is increasingly dependent on online customer satisfaction evaluations expressed by means of ORs (Ye et al., 2009; Yang et al., 2018). Accordingly, in today's competitive environment, hotels' performance is increasingly dependent on ORs also known as electronic word-of-mouth (eWOM) (Hennig-Thurau et al., 2004) that has been found to play a crucial role for hotels' bookings, revenues, and financial performance (Ye et al., 2009; Kim \& Park, 2017; Yang et al., 2018) but also for online consideration and reputation which is a relevant non financial short-, medium- and longterm objective for hotel companies (Vermeulen and Seegers, 2009; Yacouel and Fleischer, 2011). Despite the crucial and increasing role that eWOM plays in driving hotel firms' performance (Yang et al., 2018), and the empirical evidence that social media rating represents a more significant predictor than traditional customer satisfaction to explain hotels' performance (Kim \& Park, 2017), thus far studies dealing with hotel efficiency (e.g., Assaf et al., 2010; Barros, 2005; Yin et al., 2015) have never taken into account eWOM. This is rather surprising as the literature adopting an efficiency approach to hotel performance is well developed (see Sainaghi et al., 2017 for an updated literature review).

Therefore, the aim of the paper is to bridge the aforementioned research gap and embed eWOM into the measurement of hotel efficiency. More specifically, we embed eWOM stemming from OTAs (i.e., Booking.com) in efficiency DEA modelling, based on a relevant sample of hotels located in Rome, Italy.

Furthermore, we make our analysis more robust by carrying out a sensitivity analysis on the outputs of the model which are the focus of the analysis, with the aim of comparing their role in infleucning the overall efficiency of the hotels.

The paper is organized as follows. Section 2 presents the review of the literature dealing with performance measurement in hospitality (with an emphasis on DEA modelling) and the relevance of the relationship between eWOM and hotel performance. The third section illustrates the methods deployed. Section 4 elucidates the research findings. The fifth section portrays the theoretical and managerial implications of the study. The last section identifies the study's limitations and avenues for future research. 


\section{Literature Review}

\subsection{EWOM and performance in the hospitality sector}

Development in digital technologies has brought about a multiplication of user generated content in a number of forms including posts on social media and online reviews (ORs). In particular, the latter ones allow actual and potential consumers to articulate and share their perceptions about products, services and experiences on the Internet and have been represented through the concept of electronic word-of-mouth (eWOM) (HennigThurau et al., 2004). More specifically, eWOM is defined as 'any positive or negative statement made by potential, actual or former consumers about a product or company, which is made available to a multitude of people and institutions via the Internet' (Hennig-Thurau, Gwinner,Walsh, \& Gremler, 2004, p. 39). ORs and eWOM have increasingly become a popular heuristics for potential hotel guests to make informed purchasing decision (Gretzel \& Yoo, 2008; Nielsen, 2015) and share their opinions after a hotel stay. Therefore, there has been an escalation of interest in eWOM on behalf of hospitality management scholars as clear from recent literature reviews (Cantallops \& Salvi, 2014; Kwok et al., 2017; Mauri \& Minazzi, 2013). Based on the literature review of eWOM conducted by Cantallops and Salvi (2014) in the hospitality industry, extant studies could be classified in two main research lines: research on online review generating factors (e.g., Casalo' et al., 2010) and the impact of the online reviews on consumers (e.g., Vermeulen \& Seegers, 2009) and on companies (e.g., Ye et al., 2009).

Within the research strand examining the impact of the ORs on consumers, Vermeulen and Seegers (2009) find that the more consumers are exposed to ORs the higher their hotel consideration. Moreover, they empirically observe that positive reviews improve consumer attitudes toward hotels, ultimately contributing to enhance the e-reputation of the hotel. Consequently, enhancing the online reputation of a hotel is an end in itself. Accordingly, in the short-, medium- and long-term term online reputation can be considered an objective in itself for the hotel that might be conducive to get price premiums, thus improving competitive positioning (Yacouel and Fleischer, 2011) and ultimately financial performance.

If we shift our attention to the studies looking at the impact of eWOM on hotel performance, they have mostly examined the association of certain quantitative features of hotels' online reviews, such as valence (i.e., the rating), volume (i.e., the number of reviews) and variance (i.e., the variation in ratings) with hotel's performance measured through financial and non-financial metrics such as revenue per available room (RevPAR) (e.g., Ye et al., 2009, 2011), average daily rate (ADR) (e.g., Ye et al., 2011; Phillips et al., 2015) and occupancy (e.g, Viglia et al., 2016). In their meta-analysis of 25 empirical studies capturing the relationship between eWOM and hotel performance, Yang et al. (2018) conclude that eWOM valence elasticity (0.888) is twice as large as its counterpart in the general marketing field (0.417) and much higher than the volume elasticity $(0.055)$ that is in its turn much lower than its counterpart $(0.236)$ in the marketing field.

As clear from recent literature reviews (Kwok e al., 2017; Yang et al., 2018), despite the presence of a small yet increasing number of studies trying to capture the relationship between eWOM and hotel performance, none of them has adopted an efficiency-related approach to hotel performance. To bridge this gap, we leverage on a well-known approach to analyze hotel efficiency such as the Data Envelopment Analysis (DEA) - whose 
applications in the hospitality management literature are illustrated in the following section - and embed eWOM into it. To our knowledge, this is the first paper to embed customer satisfaction measured through online consumer reviews (i.e., eWOM) into a DEA model.

\subsection{Performance measurement and hotel efficiency in the hospitality sector}

Performance measurement is a complex, multilevel, multi-dimensional, and interdisciplinary research domain whose main features within the hospitality and tourism sector have been described recently through systematic literature reviews (Altin et al., 2018; Sainaghi et al., 2017).

In their literature review, Sainaghi et al. (2017) categorize tourism and hospitality studies related to performance measurement along three different dimensions: 1) disciplinary field (i.e. accounting and financial management, economics, and strategy); 2) unit of analysis (i.e., destination, cluster, firms); and 3) approaches (i.e., efficiency, competitiveness, productivity, metrics in use, performance measurement systems).

As far as the approaches to measure performance are concerned, there is a wide range of methodologies that have been developed to assess the efficiency of organizational units (Coelli et al. 2005). Efficiency approaches have leveraged analysis techniques such as Data Envelopment Analysis (DEA) (e.g., Perrigot et al., 2009), Stochastic Frontier Analysis (SFA) approaches (e.g., Chen, 2007), Importance-performance analysis (IPA) (e.g. Chen, 2014). In the next section we illustrate one of the most relevant analytical tool used when measuring companies' efficiency: Data Envelopment Analysis (DEA) (Charnes et al., 1978) and describe how it has been used so far in hospitality management literature to assess hotels' efficiency.

\subsubsection{Applying DEA methodologies to measure hotel efficiency}

Measuring hotels' efficiency implies comparing their capability to transform one or more inputs into one or more outputs. Among the range of methodologies that have been developed for efficiency assessment (Coelli et al. 2005), production/cost frontiers play a dominant role in the hospitality and tourism industry. Even though part of the literature has adopted parametric stochastic approaches for evaluating efficiency (Anderson et al., 1999), most of the scholars have applied Data Envelopment Analysis (DEA) so far (e.g., Guizzardi et al., 2016; Huang, 2017).

DEA is a non-parametric linear-programming technique and methodological approach developed in the second half of the seventies (Charnes et al., 1978) and is extensively embraced to assess the efficiency of economic entities, also termed as Decision Making Units (DMUs), converting multiple inputs into multiple outputs. DEA branches into a wide family of models that have the common goal to measure for each DMU an 'efficiency score' defined as the maximum value of the ratio of the weighted sum of outputs to the weighted sum of inputs. DEA models display a number of advantages compared to other efficiency measurement approaches: a) they can manage multiple inputs-multiple outputs; b) they do not require the specification of the production/cost function; and c) they work well with small samples. However, DEA also displays several limitations (Coelli et al., 2005): (i) they assume that the inputs and outputs taken in consideration are measured without noise; (ii) 
they are sensitive to outliers; (iii) they show a large percentage of efficient DMUs when the number of observations is low compared to the number of inputs and outputs.

The DEA approach has been extensively applied to the hospitality industry, as clear from Table 1 that encompasses the main articles using DEA between 2013 and 2017.

\section{[Insert Table 1 about here]}

DEA applications to the hospitality industry can be classified along several dimensions. The first dimension is the specific unit of analysis. Even if most of the studies deal with the performance of the hotel as a single unit (Guizzardi et al., 2016; Huang 2017; Ramanathan et al. 2016), there are examples of evaluations at a higher or lower level of aggregation. Several studies focus on the performance of specific regions or metropolitan areas (Cuccia et al. 2016; Luo et al., 2014), while others dig in more depth and, within each hotel, separately evaluate the performance of individual attributes of the hospitality service such as the restaurant and/or the wellness center (Yin et al., 2015; Huang et al., 2015).

The second dimension is the time span of the analysis. Some studies analyze the hotels' efficiency in a single year (Huang et al., 2014; Manasakis et al., 2013), while others develop a longitudinal analysis along several years (Brida et al. 2015; Luo et al., 2014; Oliveira et al. 2014).

The third dimension relates to the specific approach adopted. The vast majority of studies adopt a Variable Return to Scale (VRS) approach (Fernandez \& Becerra 2015; Brida et al. 2015), also termed as BCC (from the the initials of the scholars Banker, Charnes and Cooper - Banker et al. 1984). A VRS approach assumes that the efficiency in transforming inputs into outputs is affected by the volume of the inputs/outputs, so that economies/diseconomies of scale exist at different volume levels. Another set of studies have embraced the Constant Return to Scale (CRS) approach (Ben Aissa \& Goaied 2016; Brown \& Ragsdale 2002; Hwang \& Chang 2003; Ramanathan et al., 2016) also termed as CCR (from the scholars Charnes, Cooper and Rhodes Charnes et al. 1978). In this latter model there is an assumption that the returns to scale can be considered as constant in the hotel industry, regardless of the volume.

A few researchers have applied both BCC and CCR in order to evaluate the scale effects (Reynolds 2003; Chiang et al., 2004; Oliveira et al., 2014). More recently, an increasing number of research works have applied advanced approaches to DEA. For instance, Luo et al. (2014) have leveraged the Malmquist index for longitudinal studies to evaluate the efficiency changes of a set of Chinese hotels in five years. Detotto et al. (2014), based on the double bootstrap method proposed by Simar and Wilson (2007), have implemented a pool truncated specification of DEA to the hospitality performance of several Italian regions, in order to overcome possible problems of serial correlation amongst the estimated efficiency scores. Huang (2017) has applied hybrid DEA to 67 Taiwanese hotels, in order to combine both radial and non-radial measures of labour efficiency.

The fourth dimension pertains to the different use of inputs and outputs. Both Input-oriented and Outputoriented models have been widely adopted. In an Input-oriented model the target is to minimize the amount of 
inputs needed for obtaining a given level of outputs. In an Output-oriented model the target is to maximize the outputs given the level of inputs used. The motivation for using Input-oriented models is that typically a company can manage only the inputs of the transformation process (Neves \& Lourenco, 2009), while studies adopting the Output-oriented models focus on the possibility to increase the main output, usually the turnover (Cuccia et al., 2016). Regardless of the orientation of the system, the inputs and outputs on which the DEA models are based are often the same or very similar. The inputs usually include two main dimensions: capital invested and labor. The level of capital invested is operationalized usually in terms of total assets, gross fixed investments (Detotto et al., 2014), number of rooms (Huang et al., 2014; Oliveira et al., 2014) or number of beds (Manasakis et al., 2013). The labour is usually measured through the number of employees (Luo et al., 2014; Fernández and Becerra, 2015) or the labour cost (Brida et al., 2015). Among the outputs, almost all of the studies include total revenues, whereas a minority also embeds measures related to the actual turnover or occupancy (occupancy rate, revenue per available room, value added).

The fifth dimension, specifically relevant for our purposes, relates to the temporality of outputs. An interesting common feature of studies applying DEA is that all the outputs selected relate to the past performance of the company, thus failing to represent the capability of the hotel to generate value in the future. Looking only at the past revenues and occupancy rates, the analysis is not able to understand and forecast whether the hotel is exploiting capital and labour inputs in order to generate value for the future.

More briefly, we can say that in DEA models applied to the hospitality sector there is a lack of leading indicators, i.e. KPIs able to represent the critical factors to manage in order to increase the future performance (Gray et al. 2014). If well-chosen and set, leading indicators can provide a relevant support to the strategic management of a company's performance (Chenhall 2005). Moreover, among leading indicators, customer satisfaction has been proved to be a driver of future financial performance (Ittner and Larcker, 1998; Luo and Homburg 2007) as it affects customer loyalty which in turns positively impacts repurchase intentions that ultimately translate into higher revenues and profits. This relationship has also been found in the hospitality sector (Assaf \& Magnini, 2012; Assaf et al., 2015; Chi \& Gursoy, 2009; Hua et al., 2018).

To date virtually none of the studies reviewed has included customer satisfaction among the outputs of DEA applications. The only study in the wider efficiency measurement related literature encompassing customer satisfaction has deployed a distance stochastic frontier to compare the efficiency results of eight leading US hotel chains from two Stochastic Frontier models, one including customer satisfaction (measured through a traditional customer satisfaction index) as an output variable and one excluding customer satisfaction (Assaf $\&$ Magnini, 2012). The authors find that excluding customer satisfaction may lead to significant difference in the mean and ranking of hotel efficiency scores. However, their study does not use DEA and relies on a traditional measure of customer satisfaction which is the American Customer Satisfaction Index (ACSI) (Fornell et al., 1996) that relates to brands and companies (rather than individual products and services) available in the US. While similar indexes have been introduced in a number of other countries (such as the UK), they do not necessarily cover all countries and their underlying methodology might slightly differ. As a consequence and given that ORs have been recently found to be a better proxy of customer satisfaction than 
traditional customers satisfaction measures (Kim \& Park, 2017), we propose to rely on eWOM to enrich extant measures of efficiency in DEA models.

Our study is therefore distinctive for the following reasons. First, we deploy a DEA approach to measure hotels' efficiency and include innovatively among the outputs also customer satisfaction as a fundamental leading indicator. Second, instead of leveraging on customer satisfaction indexes, we build on online customer satisfaction in the form of eWOM as an output of our model to understand how this could affect efficiency scores and rankings. ORs have many advantages over customer satisfaction indexes (CSIs): a) they are available also in countries where CSIs are not present and or not reliable; b) they are a more fine-grained and precise metric of customer satisfaction with hotel services as they relate to the specific product/service purchased and not to a generic brand. Third, we focus on independent hotels that are our Decision Making Units (DMUs): accordingly, we are able to match perfectly financial with customer satisfaction measures at the individual hotel property level. Fourth, we control the findings of the comparison between DEA efficiency results without and with eWOM by hotel class, by capturing if and to what extent the discrepancy in terms of DEA-measured efficiency is a consequence of hotel class. Last, we situate our study in Italy which ranks in the top 5 countries in terms of international tourist arrivals (UNWTO, 2018) and in the top 10 in terms of international tourism receipts: this allows to validate and extend previous findings obtained in the United States: on one hand, this represents a meaningful empirical setting that has been rarely investigated by using DEA approaches; on the other hand, this allows us to validate and extend previous findings obtained through stochastic frontier approaches within the US context. 


\section{Methodology}

\subsection{Sample selection and data collection}

Rome was chosen as empirical setting because it ranks thirteen worldwide and third in Europe as a city destination (Euromonitor, 2017) and is somehow neglected in DEA-related efficiency studies.

As far as ORs are concerned, data was retrieved using a crawler written in the Python language. The crawler allowed us to extract online review data related to the overall population of hotels $(\mathrm{N}=858)$ located in Rome and listed on the Booking.com platform in 2015. As proxies of customer satisfaction we deployed the valence (rating) of online reviews in line with the most recent literature (Yang et al., 2018). Online ratings, also known as OR valence, have been found to be the most relevant feature of eWOM affecting hotel performance (Yang et al., 2018).

Customer satisfaction data were matched with available financial data. We searched and collected the financial statements of individual hotels from the financial database AIDA (Bureau Van Djik), with an emphasis on revenues, operating costs and number of employees. Out of the overall number of Rome-based hotels that were listed on Booking, we were able to identify the financial reports of 340 independent hotels, as the remaining 518 are part of large and small hotel chains or included in companies involved in several businesses (house renting, restaurants, etc.). This second group of hotels was excluded from the final sample as it was not possible to identify exactly revenues, operating costs and number of employees of the individual DMU (i.e., the individual hotel) in larger companies dealing with multiple other businesses or even in chains as the financial statements (including the income statement) do not provide a breakdown of revenues, operating costs and number of employees by individual hotel.

For the 340 selected independent hotels we collected the following data related to year 2015 from the AIDA database: total revenues, operating cost, labour cost and number of employees. We also computed the percentage operating margin (operating margin/revenues). Starting from these data, we performed a reliability check, ruling out of the analysis the hotels for which the risk of unreliable financial data seemed high. More specifically, we excluded the hotels with: a) revenues lower than $100.000 €$; b) a percentage operating margin higher than $50 \%$ or lower than $-50 \%$. Based on these criteria, 72 other hotels were excluded from the sample, leaving 268 valid units of analysis including 2-star hotels (13), 3-star hotels (133), 4-star hotels (111) and 5star hotels (11) whose distribution mirrors the prevalence of 3-star and 4-star hotels in the destination. To control for potential confounding effects, stemming from the different levels of customer satisfaction and expectations when taking into account different features of hospitality firms' marketing, reputational, and managerial issues (Park \& Allen, 2013), we broke down our sample into two subsamples: higher-end hotels (4- and 5- star hotels) and midscale-budget hotels (2-and 3-star hotels) and we conducted our analysis on the two separate subsamples. 
Based on previous literature (see section 2.2), we identified our inputs in the following three variables: number of rooms, number of employees, total operating expenses net of the cost of labor ${ }^{1}$. Furthermore, we considered two outputs: the total revenues as a metric to capture financial performance and online ratings as a proxy of online customer satisfaction and a proxy of hotel online reputation.

Consistently with Assaf \& Magngini (2012), we include customer satisfaction among the outputs rather than among the inputs in efficiency studies. In addition to the mentioned study, we justify the reason of including eWOM among the outputs on the premise that hotel companies actively look for higher levels of e-reputation as a short-, medium- and long-term objective (Yacouel and Fleischer, 2011) with an immediate measurable effect in the short term. All the financial data (revenues and operating costs net of labor cost) and the number of employees was collected from the database AIDA, while the number of rooms was obtained from different sources, making sure they were consistent: the hotels' website, the Booking.com website or through direct inquiries with the hotels.

\subsection{Data analysis}

In line with a relevant stream of literature, (Ramanathan et al., 2016; Huang et al., 2015) we selected an inputoriented DEA model, because the inputs are what is directly actionable by the managers and what can be affected by managerial initiatives. Before running the final DEA model, we further cleaned the dataset by dropping all the hotels with a number of reviews lower than 100, consistently with extant eWOM literature in the hospitality industry (Schuckert et al., 2015). Accordingly, we removed five hotels from the 2-3 stars subsample (ranging from 32 to 89 reviews) and five from the 4-5 stars subsample (ranging from 67 to 82 reviews). Therefore, the final samples consist of 141 budget/midscale hotels (i.e., 2- and 3-star hotels) and 117 higher-end hotels (i.e. 4- and 5-star hotels) that cover a very large share of independent hotels listed on Booking for the selected destination.

A descriptive representation of the ORs analyzed and respective hotels is presented in Table 2.a while Table 2.b includes the descriptive statistics related to ORs.

\section{[Insert Table 2.a about here] \\ [Insert Table 2.b about here]}

Second, we applied the Banker and Gifford (1988) super-efficiency approach to identify the DMUs with anomalous efficiency values that could be related to low quality data reporting or specific environmental operating conditions. Basically, the super-efficiency approach differs from the basic DEA model, because the DMU under evaluation is excluded from the reference set, so that its efficiency score can be higher than

\footnotetext{
${ }^{1}$ We excluded the cost of labor from the operating expenses because it was already partially represented as an input by the number of employees. The remaining operating cost are mainly due to raw materials, services, depreciations and rents.
} 
$100 / 100$. The higher the efficiency score, the higher the risk of affecting and distorting the whole frontier and the score of the whole set of DMUs. Although the super efficiency procedure has also been proposed for ranking efficient suppliers (Andersen \& Petersen, 1993), it performs best when used to identify and eliminate outliers (Banker \& Chang 2006). We applied it to the two subsamples setting the threshold of maximum efficiency score at 120/100 as accepted by the literature (Banker \& Chang 2006). We ruled out 5 DMUs from the 2-3 star hotels subsample and 6 from the 4-5 star hotels subsample. At the end of this further refinement of sampling, 136 hotels remained in the 2- and 3-star hotels subsample and 111 in the 4- and 5-star hotels subsample, totaling to 247 DMUs. The number of the DMUs included in the two subsamples is largely above the minimum threshold needed for DEA analyses, given the low number of inputs and outputs (a maximum of 3 inputs and 2 outputs in the most complex DEA model). Table 3 reports the descriptive statistics of the variables related to inputs and outputs in the final sample.

\section{[Insert Table 3 about here]}

We applied an Input-Oriented BCC-DEA model. We selected a variable return-to-scale model (BCC), because returns in the hotel industry are affected by the size of the input and output vectors, as accepted by most of the previous literature (Luo et al. 2014, Fernandez and Becerro 2014, Detotto et al. 2014, Huang et al. 2015).

In the basic formulation of DEA (CCR model), given a set of $n$ DMUs $(j=1, \ldots, n)$, the technical efficiency (TE) of the jth DMU $\left(\theta_{j}\right)$ can be calculated as the ratio between the weighted sum of its outputs and the weighted sum of its inputs.

$$
\theta j=\frac{\sum_{i=1}^{n} u_{i j} y_{i j}}{\sum_{r=1}^{m} v_{r j} x_{r j}}
$$

where $u_{i j}$ is the weight of the ith output for the jth DMU $\left(y_{i j}\right)$ and $v_{r j}$ is the weight of the rth input for the jth DMU $\left(x_{r j}\right)$. The problem of maximizing $\theta j$ can be solved by either maximizing the numerator while keeping constant the denominator (output-oriented model) or by minimizing the denominator while keeping constant the numerator (input-oriented model). As said, we applied an input-oriented model.

The minimization problem can be solved through linear programming as follows:

$$
\begin{gathered}
\operatorname{Max} \theta j\left(y_{j}, u_{j}, x_{j}, v_{j}\right)=\frac{\sum_{i=1}^{n} u_{i j} y_{i j}}{\sum_{r=1}^{m} v_{r j} x_{r j}} \\
\text { s.t. } \sum_{i=1}^{n} u_{i j} y_{i j}-\sum_{r=1}^{m} v_{r i} x_{r j} \leq 0 ; j=1, \ldots, n
\end{gathered}
$$




$$
\begin{gathered}
\sum_{i=1}^{n} u_{i j} y_{i j}=1 \\
u_{i j} \text { and } v_{r j}>\varepsilon,
\end{gathered}
$$

where $\varepsilon$ represents a non-archimedean value which purpose is that of enforcing strict positivity on the weights.

The BCC model (Barnes et al. 1984) represents a general extension of the CCR model that allows a variable return to scale in the transformation of inputs into outputs.

$$
\begin{gathered}
\operatorname{Max} \dot{\theta} j\left(y_{j}, u_{j}, x_{j}, v_{j}\right)=\frac{\sum_{i=1}^{n} u_{i j} y_{i j}-u_{0}}{\sum_{r=1}^{m} v_{r j} x_{r j}} \\
\text { s.t. } \sum_{i=1}^{n} u_{i j} y_{i j}-u_{0}-\sum_{r=1}^{m} v_{r i} x_{r j} \leq 0 ; j=1, \ldots, n \\
\sum_{i=1}^{n} u_{i j} y_{i j}=1 ; u_{i j}>\varepsilon ; v_{r j}>\varepsilon
\end{gathered}
$$

where $\dot{\theta}$ represents the pure technical efficiency (PTE) of the jth DMU. The ratio between TE and PTE provides the scale efficiency (SE) at which the specific DMU operates. All the analyses (including the above mentioned super efficiency model) were developed using the PIM-DEA software version 3.2.

To carry out the DEA analysis, based on the application of equation (1), we ran two DEA models for each of the two subsamples (2- and 3- star and 4-5 star): one with revenues as the only output (model 1), and one with both revenues and online ratings as outputs (model 2). By comparing the efficiency scores and rankings generated by the two models, we evaluated the impact of introducing the online rating into the DEA model.

\section{Findings}

The effects associated with the introduction of eWOM (proxied though online ratings) in the DEA model for the subsample of 2- and 3-star hotels ( $\mathrm{n}=136)$ on the efficiency score (from 0 to 100/100) and on the related efficiency ranking (from 1 to 136) are illustrated in Figures 1 and 2 respectively. The hotels are presented from the least efficient (hotel 1) to the most efficient (hotel 136), as ranked by model 1 . As a consequence, while the efficiency score increases, the ranking position decreases, because all the efficient hotels are ranked first, while the less efficient hotel is ranked 136th.

[Insert Figure 1 about here]

[Insert Figure 2 about here] 
It is well known that the variation of efficiency scores generated by the introduction of one or more inputs or outputs in a DEA model is non-negative (Coelli et al. 2005). As a consequence, Figure 1 shows increasing or constant DEA scores once the online review valence is included in the model. With the Revenues as the only output of the model, 33 hotels are efficient and obviously, being the variation non-negative, their score remains equal to 1 after adding the new output. Out of the remaining 103 hotels, 20 (19.4\% of the total) show an increase in the efficiency score. On average the increase is equal to $10.35 / 100$, with a maximum of $35.4 / 100$ and a minimum of $0.9 / 100$. The remaining 83 hotels maintain the same efficiency score.

As far as the efficiency rankings are concerned (Figure 2), we observe 7 additional efficient hotels; moreover, 74 hotels ( $72 \%$ of the inefficient ones) display a different ranking. Table 4 reports the magnitude of the variation of the rankings generated by the introduction of the online review valence in the DEA model.

\section{[Insert Table 4 about here]}

Among the 74 hotels displaying a rank variation, 37 move to similar positions (improving or decreasing their rank by 1 to 5 positions), 25 show a relevant effect (displaying a difference from 6 to 10 positions) and 12 a very important change (more than 10 positions). As shown by the last two columns of Table 4, the DMUs increasing their position in the overall ranking (we label them as "Improvers") show high variations in the ranking: 12 out of 19 improve their position by more than 10 positions. On the other side, the number of DMUs showing a worse position in the ranking (we label them as "Receders") is much greater (55 vs. 19), but the average variation is much smaller: 33 DMUs show a variation lower than 6 positions, 22 between 6 and 10 positions, while none of the them shows a decrease higher than 10 positions. While the Improvers on average increase their ranking by 27.3 positions, the Receders lose on average only 4.9 positions.

In the following table (Table 5) the main features of "Improvers" and "Receders" are reported, together with the hotels that maintain their position in the ranking and those already efficient when Revenues were the only output. Even if the average values related to Revenues, Rooms and Employees for the "Receders" are higher than for the "Improvers", the difference of the average values is not statistically significant. What is highly significant is the difference between the online review valence of the two groups: the average value for the "Improvers" (8.8) is much higher than for the "Receders" (8.0) $(\mathrm{t}=6.074$; $\mathrm{p}$-value=0.000).

\section{[Insert Table 5 about here]}

Afterwards, by applying equation [1], we ran an additional DEA model, keeping constant the three inputs (number of rooms, employees and net operating expenses), while considering the online rating as the only output. By excluding from the outputs of the most comprehensive model (model 2) the revenues, we developed a sensitivity analysis, through a "One-Factor-At-a-Time" (OFAT) approach (Daniel 1973) to assess the role played by the revenues in determining the overall efficiency of the hotels. Taking into account the online ratings as the only output, the DEA estimation generates 29 efficient hotels that, as mentioned, remain efficient 
in Model 2, because the efficiency variation is non-negative when an output or input is introduced in the DEA model. Out of the remaining 107 hotels, 104 (97\%) show an increase in efficiency when the revenues are introduced in the model (difference between the results of model 2 and 3). On average the increase is equal to 28.1/100, with a maximum of 87.5/100 and a minimum of 0.9. As for the efficiency rankings, still considering the 107 hotels that are inefficient when considering only online ratings s output, 99 (93\% of the total) show a variation of the ranking higher than 5 positions when the revenues are introduced in the model. All in all, the sensitivity analysis developed on 2- and 3-star hotels clearly highlights a predominant role of the revenues over the online ratings in affecting the overall efficiency of the hotels though online ratings contribute to the efficiency of the selected organizations.

As far as the 4- and 5-star hotels are concerned, figures 3 and 4 show the impact on efficiency score and ranking generated by the introduction of the online review valence in the DEA model.

\section{[Insert Figure 3 about here] \\ [Insert Figure 4 about here]}

For higher-end hotels, out of the initial 84 inefficient hotels, 32 (38\%) show an increase in the efficiency score. The average increase of these units is $4.3 / 100$, ranging from $1.16 / 100$ to $21.3 / 100$. It is rather interesting to observe that for higher end hotels the average increase is lower than for budget hotels (it was 10.35): this seems to reflect the well-known structural differences of hotels across class and the way they are embedded in customer satisfaction metrics (Park \& Nicolau, 2015).

Looking at the rankings (Figure 4) the introduction of the online review valence in the DEA model adds 6 efficient units to the initial 27 and overall 62 hotels show a different ranking. The magnitude of the ranking variation is presented in Table 6.

\section{[Insert Table 6 about here]}

More than $30 \%$ of the inefficient hotels show a significantly different position in the ranking (more than 5 positions): $22.6 \%$ from 6 to 10 positions and $9.5 \%$ over 10 positions. Also in this case, the average variation of the "Improvers" is much higher than the average variation of the "Receders": 14 positions for the former ones, 4.2 positions for the latter ones. Again, all the huge variations in the ranking (over 10 positions) are generated by the Improvers (8 DMUs).

Finally, Table 7 presents the main features of the "Improvers" and the "Receders" in the 4-5 stars category, compared to the other hotels. In this second subsample the size of the "Receders" is higher than the "Improvers". The difference is statistically significant at a 0.05 level for the variables "Rooms" and "Employees" ( $\mathrm{t}$ values respectively equal to -2.426 ad -2.009 ; $\mathrm{p}$-values respectively equal to 0.018 and 0.049 ) and at a 0.10 level for the variable "Revenues" ( $\mathrm{t}$ value equal to -1.764 ; $\mathrm{p}$-value equal to 0.083 ). Again, the 
online review valence is much higher for the "Improvers" (8.7) than for the "Receders" (8.1) and the difference is statistically significant $(\mathrm{t}$ value $=4.667$; $\mathrm{p}$-value $=0.000$ ).

\section{[Insert Table 7 about here]}

Finally, we replicated for the 4- and 5- star hotels the same sensitivity analysis previously applied to the 2- and 3- star hotels. We developed an additional DEA model, where the revenues were excluded from the outputs, and compared the results with those generated by model 2, where both revenues and online rating are included as outputs. This latter model generated 22 efficient hotels. Of the remaining 89 inefficient hotels, 88 (99\%) show an increase in efficiency when the revenues are included among the outputs. On average the variation is equal to $38.5 / 100$, ranging from $0.2 / 100$ to $95.2 / 100$. With the introduction of online ratings among the outputs (variation between model 1 and 2), only $38 \%$ of the hotels increased their efficiency score and the average variation was much lower $(4,3 / 100)$.

As for the rankings, focusing on the 89 inefficient hotels, 75 (84\%) show a relevant different ranking (variation higher than 5 positions) once the revenues are included in the model. The same analysis generated a result equal to $32,1 \%$ when the online rating was introduced.

Table 8 summarizes the results of the sensitivity analysis on the two subsamples, showing the relative impact of introducing either online ratings or revenues into the DEA model.

\section{[Insert Table 8 about here]}

\section{Discussions and conclusions}

\subsection{Concluding remarks}

Based on our empirical analysis, it seems that embedding customer satisfaction in the form of eWOM generated through online consumer reviews into DEA models generates interesting results both for DEArelated studies and for the wider efficiency related literature. More specifically, our findings show that embedding customer satisfaction within DEA models generates an increase in efficiency equal to 10.35/100 for midscale-budget hotels (2- and 3-star hotels) and 4.3/100 for higher-end hotels (4- and 5- star hotels) Simultaneously, looking at the variations in the efficiency ranking generated by the introduction of the customer satisfaction into the DEA model, we detected that $36 \%$ of $2-3$ star hotels and $32,1 \%$ of the $4-$ and 5 star hotels move significantly in the ranking (more than 5 positions up or down). Overall, the introduction of online customer satisfaction among the outputs of the DEA model endangers differentiated effects in the efficiency rankings, so that several hotels improve and other recede in their respective rankings.

Interestingly, when controlling by hotel stars, it emerges clearly that online customer satisfaction makes a higher difference on average for 2- and 3-star hotels than for 4- and 5- stars. This applies also to the modification in the efficiency ranking. Accordingly, embedding eWOM as an output of DEA models generates differentiated impacts across hotel classes. This finding is consistent with literature showing that hotel online 
ratings' distributions vary across hotel class (Mariani \& Borghi, 2018) and explains much of hotel performance (Yang et al., 2018).

At the same time, the sensitivity analysis conducted through the OFAT approach showed that revenues play a relevant role in affecting the overall efficiency, consistently with all previous DEA studies that include revenues or revenues-related measures among the outputs of the model (see Table 1). Overall, while financial performance and online reputation are clearly linked to each other, it is extremely clear that hotel companies are striving to get both higher levels of reputation (Yacouel and Fleischer, 2011) and higher levels of financial performance (Yang et al., 2018).

\subsection{Theoretical implications}

This study makes several important theoretical contributions to the literature of DEA-based efficiency applied to the hospitality sector. First, to our knowledge this is the first study embedding customer satisfaction in DEA application to the hotel. Thus, we embrace a multi-dimensional approach to hotels' performance which allows to break the silo approach to DEA- based efficiency measurement that has dealt mainly with economic and financial metrics so far and not with customer satisfaction or other leading indicators. We should however acknowledge that customer satisfaction has been applied in the wider efficiency studies field in a previous study (Assaf \& Magnini, 2012) leveraging distance stochastic frontier analysis. Second, our study provides a validation and extension of Assaf \& Magnini's (2012) findings as we find that introducing measures of customer satisfaction into efficiency models generates a variation in the relative efficiency rankings of hotels and those hotels that improve, make a substantial improvement. This seem to strengthen the idea that performance is a multi-dimensional concept for hospitality firms (Elbanna et al., 2015; Sainaghi et al., 2013) and this multi-dimensionality should be taken into account in efficiency related studies. Third, our study is innovative as it gauges customer satisfaction by means of eWOM instead of customer satisfaction indexes. This seems a more effective way to introduce customer satisfaction into efficiency related studies as ORs a) are available also in countries where customer satisfaction indexes (CSIs) are not present and/or not reliable; b) they are a more fine-grained and precise metric of customer satisfaction with hotel services as they relate to the specific product/service purchased/experienced and not to a generic brand. Moreover, ORs are increasingly becoming a better proxy of customer satisfaction than traditional customers satisfaction measures (Kim \& Park, 2017). Fourth, and related to the previous point, we juxtapose more traditional metrics that are often rather static with real-time digital data streams that are able to capture effectively online customer satisfaction and simultenously the firm's online reputation. Last, we control the findings of the comparison between DEA efficiency results without and with eWOM by hotel class, by capturing if and to what extent the discrepancy in terms of DEA-measured efficiency is caused and/or affected by hotel class.

\subsection{Practical implications}

This study generates an interesting set of managerial implications for managers in the hospitality sector. First, as eWOM is becoming increasingly salient for hotels' performance (Yang et al., 2018), hotel managers should 
embed it increasingly into their companies' performance assessment and performance measurement systems (PMSs): this might provide them with a more accurate, nuanced, and comprehensive picture of the performance of their firm and perhaps would also modify the way their company's performance is made sense of and interpreted. Second, as embedding eWOM into DEA related efficiency models clearly generates a modification in the efficiency ranking across hotels, we would expect PMSs to reflect these differences and encourage managers to redefine and strengthen their competitive performance benchmarks vis-à-vis the comp set of hotels operating in the same destination. Third, hotels can empower their PMSs in order to support their strategy development process thus shaping e-WOM-informed Strategic Performance Measurement System (SPMS Chenhall 2005, Gimbert et al., 2010, Silvi et al., 2015) whereby e-WOM would allow to integrate financial and non-financial indicators and implement a forward-looking perspective (as customer satisfaction is contemplated as a main driver of future performance). Fourth, and related to the previous point, the deployment of eWOM within PMSs could allow managers to take into account explicitly the firm's online reputation among the relevant performance measurement indicators: the variation in performance leveraging a measure of reputation (eWOM) could be useful as an indicator of the "sustainability" of efficiency levels in the medium term. Fifth, the development of a eWOM-informed DEA model might allow inefficient hotels to identify efficient hotels with the most similar inputs-outputs combination (i.e. the closest to the efficient frontier) thus defining a useful benchmark to revise strategic or operational decisions. For instance, hotels' managers could analyze online customers' satisfaction with the individual service attributes (e.g., cleanliness, comfort, facilities, staff, value for money, location, wifi, etc.) of benchmark hotels to understand on what service attribute they have to invest more to enhance the overall performance of their companies. Sixth, eWOMinformed DEA models might offer guidance to managers in relation to action each input (reduction) or output (increase) in order to reach the efficient frontier. Accordingly, managers (both general managers and marketing managers) might become aware of the online ratings' increase (or the operating costs' reduction) needed to become efficient. These variations on inputs or outputs needed to reach the frontier are named "distance measures" (Aparicio et al. 2007; Baek \& Lee 2009) and, once analyzed and interpreted, could support the definition of motivating targets during the budgeting process. Based on the distance measures provided by the DEA model, hotels' managers could therefore set the required increases for revenues and online ratings or the required reduction for the number of employees or other costs. Undeinably, the role of hotels' managers and their experience would still be critical to understand which input/output is actionable and which target measure could generate a positive motivation and a real incentive for the employees. Last, eWOM-informed DEA models could inform a better dialogue between employees working in marketing with employees working in other functions thus improving a market-oriented culture whereby online marketing is perceived in an interfunctional manner.

\subsection{Limitations and suggestions for future research}

This study is not without limitations. First the study was conducted on a specific destination and sample of hotels; therefore, our findings should be validated covering more destinations (Assaf et al., 2017) to ensure 
that they could be generalized to other contexts and taking into account also hotel chains and other factors of heterogeneity such as seasonality. Second, we have adopted a variable return to scale DEA model; however, this reflects the assumption of no scale effects in line with many other studies in the literature (Detotto et al., 2014; Brida et al., 2015; Luo et al., 2014). Adopting constant returns to scale DEA model we could also capture potential scale effects if present. Third, it might be relevant to adopt a longitudinal approach with a panel of observations to gauge the effect of time on eWOM informed DEA efficiency measures, as well as capture the interplay between inputs and outputs over a large span of time. This might reveal if there are specific causal relationships worth examining and if eWOM might be considered both as an output (as it is clearly a measure of hotel online reputation) and as an input of DEA-based efficiency models. Fourth, a further avenue for research would be to ensure that the findings are robust across different efficiency measurement approaches (e.g., stochastic DEA and variations of stochastic frontier analyses). Last, we envision that it could be interesting to analyze by means of qualitative evidence how managers would modify their behaviors and cognitive processes based on the introduction of eWOM-informed efficiency measures into their Performance Measurement Systems. 


\section{References}

Altin, M., Koseoglu, M.A. Yu, X. \& Riasi, A. (2018). Performance measurement and management research in the hospitality and tourism industry, International Journal of Contemporary Hospitality Management, 30(2), 1172-1189.

Andersen, P. \& Petersen, N. (1993). A procedure for ranking efficient units in data envelopment analysis. Management Science, 39, 1261-1264.

Anderson, R. I., Fish, M., Xia, Y., \& Michello, F. (1999). Measuring efficiency in the hotel industry: A stochastic frontier approach. International journal of hospitality Management, 18(1), 45-57.

Aparicio, J., Ruiz, J. L., \& Sirvent, I. (2007). Closest targets and minimum distance to the Pareto-efficient frontier in DEA. Journal of Productivity Analysis, 28(3), 209-218.

Assaf, A. G., Josiassen, A., Woo, L., Agbola, F. W., \& Tsionas, M. (2017). Destination characteristics that drive hotel performance: A state-of-the-art global analysis. Tourism Management, 60, 270-279

Assaf, A., Barros, C. P., \& Josiassen, A. (2010). Hotel efficiency: A bootstrapped metafrontier approach. International Journal of Hospitality Management, 29(3), 468-475.

Assaf, G., Josiassen, A., Knežević Cvelbar, L., \& Woo, L. (2015). The effects of customer voice on hotel performance. International Journal of Hospitality Management, 44, 77-83.

Assaf, G. \& Magnini, V. (2012). Accounting for customer satisfaction in measuring hotel efficiency: Evidence from the US hotel industry. International Journal of Hospitality Management, 31(3), 642647.

Banker, R. D., Charnes, A., \& Cooper, W. W. (1984). Some models for estimating technical and scale inefficiencies in data envelopment analysis. Management science, 30(9), 1078-1092.

Banker R.D. \& Gifford J.L. (1988). A relative efficiency model for the evaluation of public health nurse productivity. Pittsburg (PA, USA): Carnegie Mellon University Mimeo.

Banker, R. D. \& Chang, H. (2006). The super-efficiency procedure for outlier identification, not for ranking efficient units. European Journal of Operational Research, 175(2), 1311-1320.

Barros, C. P. (2005). Measuring efficiency in the hotel sector. Annals of Tourism Research, 32(2), 456-477.

Baek, C., \& Lee, J. D. (2009). The relevance of DEA benchmarking information and the least-distance measure. Mathematical and Computer Modelling, 49(1-2), 265-275. 
Ben Aissa, S., \& Goaied, M. (2016). Determinants of tourism hotel market efficiency. International Journal of Culture, Tourism and Hospitality Research, 10(2), 173-190.

Brida, J. G., Deidda, M., Garrido, N., \& Manuela, P. (2015). Analyzing the performance of the South Tyrolean hospitality sector: a dynamic approach. International Journal of Tourism Research, 17(2), 196-208.

Brown, J. R. \& Ragsdale, C. T. (2002). The competitive market efficiency of hotel brands: an application of data envelopment analysis. Journal of Hospitality \& Tourism Research, 26(4), 260-360.

Cantallops, A. S., \& Salvi, F. (2014). New consumer behavior: A review of research on eWOM and hotels. International Journal of Hospitality Management, 36, 41-51.

Casaló, L., Flavián, C. \& Guinalíu, M. (2010). Determinants of the intention to participate in firm-hosted online travel communities and effects on consumer behavioral intentions. Tourism Management, 31, 898911.

Charnes, A., Cooper, W. W., \& Rhodes, E. (1978). Measuring the efficiency of decision making units. European journal of operational research, 2(6), 429-444.

Chen, C. F. (2007). Applying the stochastic frontier approach to measure hotel managerial efficiency in Taiwan. Tourism Management, 28(3), 696-702.

Chen, K.-Y. (2014). Improving importance-performance analysis: The role of the sone of tolerance and competitor performance. The case of Taiwan's hot spring hotels. Tourism Management, 40, 260-272.

Chenhall, R. H. (2005). Integrative strategic performance measurement systems, strategic alignment of manufacturing, learning and strategic outcomes: an exploratory study. Accounting, Organizations and Society, 30(5), 395-422.

Chi, C.G. \& Gursoy, D. (2009), Employee satisfaction, customer satisfaction, and financial performance: An empirical examination, International Journal of Hospitality Management, 28(2), 245-253

Chiang, W., Tsai, H. \& Wang, L. (2004). A DEA Evaluation of Taipei Hotels. Annals of Tourism Research, $31,712-715$.

Coelli, T.J., Rao, D.S.P., O'Donnell, C.J. \& Battese, G.E. (2005). An introduction to efficiency and productivity analysis. Springer Science \& Business Media, New York, NY.

Cuccia, T., Guccio, C. \& Rizzo, I. (2016). The effects of UNESCO World Heritage List inscription on tourism destinations performance in Italian regions. Economic Modelling, 53, 494-508.

Daniel , C. (1973) ,“One-at-a-Time Plans,” Journal of the American Statistical Association 68, 353-360 
Detotto, C., Pulina, M., \& Brida, J. G. (2014). Assessing the productivity of the Italian hospitality sector: a post-WDEA pooled-truncated and spatial analysis. Journal of Productivity Analysis, 42(2), 103-121.

Elbanna, S., Eid, R., \& Kamel, H. (2015). Measuring hotel performance using the balanced scorecard: A theoretical construct development and its empirical validation. International Journal of Hospitality Management, 51, 105-114.

Euromonitor International (2017). Top 100 City Destinations Ranking. Retrieved from http://go.euromonitor.com/rs/805-KOK-

719/images/2017\%20Top\%20100\%20Cities\%20Destinations\%20Final\%20Report.pdf Accessed 05.06.2018

Fernández, M. A., \& Becerra, R. (2015). An analysis of Spanish hotel efficiency. Cornell Hospitality Quarterly, 56(3), 248-257.

Fornell, C., Johnson, M. D., Anderson, E. W., Cha, J., \& Everitt Bryant, B. (1996). Growing the trust relationship. Journal of Marketing, 60(4), 7-18.

Gimbert, X., Bisbe, J., \& Mendoza, X. (2010). The role of performance measurement systems in strategy formulation processes. Long Range Planning, 43(4), 477-497.

Gray, D., Micheli, P., \& Pavlov, A. (2014). Measurement madness: recognizing and avoiding the pitfalls of performance measurement. John Wiley \& Sons, London.

Gretzel, U., \& Yoo, K. H. (2008). Use and impact of online travel reviews. Information and communication technologies in tourism 2008, 35-46.

Guizzardi, A., Monti, A., \& Ranieri, E. (2016). Rating hotel quality for corporate business travel departments. International Journal of Contemporary Hospitality Management, 28(12), 2842-2863.

Hennig-Thurau, T., Gwinner, K. P., Walsh, G., \& Gremler, D. D. (2004). Electronic word-of-mouth via consumer-opinion platforms: What motivates consumers to articulate themselves on the Internet? Journal of Interactive Marketing, 18, 38-52.

Hua, N. Wei, W., DeFranco, A.L., \& Wang, D. (2018). Do loyalty programs really matter for hotel operational and financial performance?, International Journal of Contemporary Hospitality Management, 30 (5), 2195-2213.

Huang, C. W. (2017). Assessment of efficiency of manual and non-manual human resources for tourist hotel industry: an application of the hybrid DEA model. International Journal of Contemporary Hospitality Management, 29(4), 1074-1095. 
Huang, C. W., Ho, F. N., \& Chen, Y. C. (2015). Assessing the Effectiveness of Marketing Strategies in Tourist Hotels: An Illustration Using a Multi-Method Approach in Taiwan. Journal of Travel \& Tourism Marketing, 32(sup1), S15-S29.

Huang, C. W., Ho, F. N., \& Chiu, Y. H. (2014). Measurement of tourist hotels' productive efficiency, occupancy, and catering service effectiveness using a modified two-stage DEA model in Taiwan. Omega, 48, 49-59.

Hwang, S., \& T. Chang (2003). Using Data Envelopment Analysis to Measure Hotel Managerial Efficiency Change in Taiwan. Tourism Management, 24, 357-369.

Ittner, C. D., \& Larcker, D. F. (1998). Are non-financial measures leading indicators of financial performance? Ananalysis of customer satisfaction, Journal of Accounting Research, 26(Supplement), 1-34.

Kim, W. G., \& Park, S. A. (2017). Social media review rating versus traditional customer satisfaction: Which one has more incremental predictive power in explaining hotel performance? International Journal of Contemporary Hospitality Management, 29, 784-802.

Kwok, L., Xie, K. L., \& Richards, T. (2017). Thematic framework of online review research: A systematic analysis of contemporary literature on seven major hospitality and tourism journals. International Journal of Contemporary Hospitality Management, 29, 307-354.

Litvin, S. W., Goldsmith, R. E., \& Pan, B. (2008). Electronic word-of-mouth in hospitality and tourism management. Tourism Management, 29, 458-468.

Luo, H., Yang, Y., \& Law, R. (2014). How to achieve a high efficiency level of the hotel industry?. International Journal of Contemporary Hospitality Management, 26(8), 1140-1161.

Luo, X., \& Homburg, C. (2007). Neglected outcomes of customer satisfaction. Journal of Marketing, 71(2), 133-149.

Manasakis, C., Apostolakis, A., \& Datseris, G. (2013). Using data envelopment analysis to measure hotel efficiency in Crete. International Journal of Contemporary Hospitality Management, 25(4), 510-535.

Mariani, M.M, \& Borghi, M. (2018). Effects of the Booking.com rating system: Bringing hotel class into the picture, Tourism Management, 66, 47-52.

Mauri, A. G., \& Minazzi, R. (2013). Web reviews influence on expectations and purchasing intentions of hotel potential customers. International Journal of Hospitality Management, 34, 99-107. 
Neves, J. C., \& Lourenço, S. (2009). Using data envelopment analysis to select strategies that improve the performance of hotel companies. International Journal of Contemporary Hospitality Management, 21(6), 698-712.

Nielsen. (2015). Global Trust in Advertising. Retrieved from https://www.nielsen.com/content/dam/nielsenglobal/apac/docs/reports/2015/nielsen-global-trust-inadvertising-report-september-2015.pdf Accessed 16.5.2018

Oliveira, R., Pedro, M. I., \& Marques, R. C. (2014). Cost efficiency of Portuguese hotels in the Algarve: a comparative analysis using mathematical and econometric approaches. Tourism Economics, 20(4), 797812.

Park, S., \& Nicolau, J. L. (2015). Asymmetric effects of online consumer reviews. Annals of Tourism Research, $50,67-83$.

Park, S. Y., \& Allen, J. P. (2013). Responding to Online Reviews: Problem Solving and Engagement in Hotels. Cornell Hospitality Quarterly, 54, 64-73.

Perrigot, R., Cliquet, G., \& Piot-Lepetit, I. (2009). Plural form chain and efficiency: Insights from the French hotel chains and the DEA methodology. European Management Journal, 27(4), 268-280.

Phillips, P., Zigan, K., Santos Silva, M. M., \& Schegg, R. (2015). The interactive effects of online reviews on the determinants of Swiss hotel performance: A neural network analysis. Tourism Management, 50, 130-141.

Ramanathan, R., Ramanathan, U., \& Zhang, Y. (2016). Linking operations, marketing and environmental capabilities and diversification to hotel performance: A data envelopment analysis approach. International Journal of Production Economics, 176, 111-122.

Reynolds, D. (2003). Hospitality-Productivity Assessment using Data Envelopment Analysis. Cornell Hotel and Restaurant Administration Quarterly, 44(2),130-137.

Sainaghi, R., Phillips, P., \& Zavarrone, E. (2017). Performance measurement in tourism firms: A content analytical meta-approach. Tourism Management, 59, 36-56.

Sainaghi, R., Phillips, P., Corti, V. (2013). Measuring hotel performance: Using a balanced scorecard perspectives' approach. International Journal of Hospitality Management, 34, 150159.

Schuckert, M., Liu, X., \& Law, R. (2015). A segmentation of online reviews by language groups: How English and non-English speakers rate hotels differently. International Journal of Hospitality Management, 48, 143-149. 
Silvi, R., Bartolini, M., Raffoni, A., \& Visani, F. (2015). The practice of strategic performance measurement systems: Models, drivers and information effectiveness. International Journal of Productivity and Performance Management, 64(2), 194-227.

Simar L. \& Wilson P.W. (2007). Estimation and inference in two-stage, semi-parametric models of production processes.. Journal of Econometrics 136(1), 31-64.

TripAdvisor. (2018). TripAdvisor Media Center. Accessed 18.06.2018 from https://tripadvisor.mediaroom.com /

UNWTO (2018), "2017 International Tourism Results: the highest in seven years” Press Release No.: 18003, 15 Jan 18. http://media.unwto.org/press-release/2018-01-15/2017-international-tourism-resultshighest-seven-years (accessed 23/04/2018).

Vermeulen, I.E. \& Seegers, D., 2009. Tried and tested: the impact of online hotel reviews on consumer consideration. Tourism Management, 30, 123-127.

Viglia, G., Minazzi, R., \& Buhalis, D. (2016). The influence of e-word-of-mouth on hotel occupancy rate. International Journal of Contemporary Hospitality Management, 28, 2035-2051.

Wang, Y., \& Fesenmaier, D. R. (2004). Towards understanding members' general participation in and active contribution to an online travel community. Tourism Management, 25, 709-722.

Yacouel, N. \& Fleischer, A. (2011). The role of cybermediaries in reputation building and price premiums in the online hotel market, Journal of Travel Research, 50 (1), 1-8.

Yang, Y., Park, S., \& Hu, X. (2018). Electronic word of mouth and hotel performance: a meta-analysis. Tourism Management, 67, 248-260.

Ye, Q., Law, R., \& Gu, B. (2009). The impact of online user reviews on hotel room sales. International Journal of Hospitality Management, 28, 180-182.

Yin, P., Tsai, H., \& Wu, J. (2015). A hotel life cycle model based on bootstrap DEA efficiency: The case of international tourist hotels in Taipei. International Journal of Contemporary Hospitality Management, 27(5), 918-937. 
Table 1: A summary of the main literature and applications of Data Envelopment Analysis (DEA) techniques to the Hospitality Industry (2013-2017)

\begin{tabular}{|c|c|c|c|c|c|}
\hline Reference & DEA Model applied & Inputs & Outputs & Object of the analysis & Time length \\
\hline $\begin{array}{c}\text { Manasakis, Apostolakis and } \\
\text { Datseris (2013) }\end{array}$ & $\begin{array}{c}\text { CRS and VRS } \\
\text { Slack analysis of inputs and } \\
\text { outputs }\end{array}$ & $\begin{array}{c}\text { Number of Employees, } \\
\text { Number of Beds and } \\
\text { Operating Costs }\end{array}$ & $\begin{array}{l}\text { Revenues and Number of } \\
\text { Nights }\end{array}$ & $\begin{array}{l}50 \text { Superior Hotels ( } 25 \text { Independent, } \\
25 \text { under brand) }\end{array}$ & 2008 \\
\hline Peng, Huang and Wu (2013) & $\begin{array}{l}\text { Rasch Model applied to a } \\
\text { VRS Output-Oriented DEA }\end{array}$ & $\begin{array}{l}\text { Subjective indicators on } \\
\text { Likert scale converted } \\
\text { through a Rasch model }\end{array}$ & $\begin{array}{l}\text { Suitable performance } \\
\text { measures: Average occupancy } \\
\text { rate, Average room rate, } \\
\text { Average production value per } \\
\text { employee in the accomodation } \\
\text { department, Average } \\
\text { production value per employee } \\
\text { in the catering department and } \\
\text { Operating income/expense. }\end{array}$ & 56 International Tourist Hotels & 2009 \\
\hline $\begin{array}{l}\text { Detotto, Pulina and Brida } \\
\text { (2014) }\end{array}$ & $\begin{array}{l}\text { Window DEA with } \\
\text { Bootstrap. } \\
\text { VRS Input-Oriented }\end{array}$ & $\begin{array}{l}\text { Labour Costs and Gross } \\
\text { Fixed Investments }\end{array}$ & Revenues and Value Added & Hotels and Restaurants & 2000-2004 \\
\hline Luo, Yang and Law (2014) & $\begin{array}{l}\text { VRS Output-Oriented. } \\
\text { Malmquist Index }\end{array}$ & $\begin{array}{c}\text { Number of Hotels, } \\
\text { Number of Employees and } \\
\text { Fixed Asset values of } \\
\text { Properties }\end{array}$ & $\begin{array}{l}\text { Revenues and Total Tax } \\
\text { Contribution }\end{array}$ & Hotels aggregated for cities & 2001-2011 \\
\hline Huang, Ho and Chiu (2014) & $\begin{array}{l}2 \text { models (with Intermediate } \\
\text { Inputs and Outputs): Input- } \\
\text { Oriented then Output- } \\
\text { Oriented }\end{array}$ & $\begin{array}{l}\text { Operating expenses, } \\
\text { Number of Rooms, } \\
\text { Catering space and } \\
\text { Number of Employees } \\
\text { (and Marketing Expenses } \\
\text { as Intermediate Input) }\end{array}$ & $\begin{array}{l}\text { As Intermediate Outputs: } \\
\text { Occupancy service capacity } \\
\text { and Catering service capacity. } \\
\text { As Outputs of the Occupancy } \\
\text { division: Occupancy revenues } \\
\text { and Number of lodging guests. } \\
\text { As Output of the Catering } \\
\text { division: Catering revenues }\end{array}$ & 58 Taiwanese International Hotels & 2009 \\
\hline $\begin{array}{l}\text { Oliveira, Pedro and Marques } \\
\text { (2014) }\end{array}$ & Both CRS and VRS DEA & $\begin{array}{c}\text { Number of Rooms, } \\
\text { Number of Employees, } \\
\text { Number of Food \& } \\
\text { Beverage places and Other } \\
\text { Costs }\end{array}$ & Revenues & $\begin{array}{l}28 \text { Prestige Hotels in the Algarve } \\
\text { (Portugal) }\end{array}$ & $2008-2010$ \\
\hline $\begin{array}{l}\text { Fernández and Becerra } \\
\qquad(2015)\end{array}$ & VRS Output-Oriented & $\begin{array}{c}\text { Number of Rooms } \\
\text { (physical capital) and } \\
\text { Number of Workers } \\
\text { (employment) }\end{array}$ & Revenues & 166 Spanish Hotels & 2000-2009 \\
\hline Yin, Tsai and Wu (2015) & Two-layer Boostrap DEA & $\begin{array}{l}\text { ROOM department: } \\
\text { Number of Rooms, } \\
\text { Employees and Operating } \\
\text { Expenses. } \\
\text { FOOD department: Inputs } \\
\text { Employees, Operating } \\
\text { Expenses and Area }\end{array}$ & $\begin{array}{l}\text { ROOM department: Revenues } \\
\text { and Occupancy Rate. } \\
\text { FOOD department: Revenues }\end{array}$ & $\begin{array}{c}20 \text { International Tourist Hotels in } \\
\text { Taipei }\end{array}$ & 2006-2011 \\
\hline $\begin{array}{c}\text { Brida, Deidda, Garrido and } \\
\text { Manuela (2015) }\end{array}$ & VRS Input-Oriented & $\begin{array}{l}\text { Labour Costs and Physical } \\
\text { Capital }\end{array}$ & Revenues and Value Added & 50 Hotels and Restaurants in Bozen & $2002-2008$ \\
\hline Huang, Ho and Chen (2015) & VRS Input-Oriented & $\begin{array}{c}\text { Total employees for } \\
\text { occupancy division, Total } \\
\text { employees for catering } \\
\text { division, Number of } \\
\text { Rooms, Total catering } \\
\text { space, Total catering } \\
\text { expenses } \\
\end{array}$ & $\begin{array}{l}\text { Revenues from occupancy } \\
\text { division, Revenues from } \\
\text { catering division and Number } \\
\text { of Guests }\end{array}$ & 68 Taiwanese 5 stars Hotels & 2012 \\
\hline $\begin{array}{l}\text { Guizzardi, Monti and Ranieri } \\
\text { (2016) }\end{array}$ & VRS model & 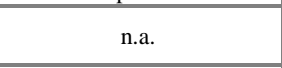 & n.a. & 538 Italian Hotels & $2012-2013$ \\
\hline $\begin{array}{l}\text { Zaman, Botti and Vo Thanh } \\
\text { (2016) }\end{array}$ & $\begin{array}{l}\text { Both CRS and VRS output } \\
\text { oriented }\end{array}$ & $\begin{array}{l}\text { Number of Rooms and } \\
\text { Operating Costs }\end{array}$ & $\begin{array}{c}\text { Revenues (and Revenues per } \\
\text { available room in the VRS } \\
\text { model) }\end{array}$ & 12 Hotels in Paris & 2014 \\
\hline $\begin{array}{l}\text { Ramanathan, Ramanathan } \\
\text { and Zhang (2016) }\end{array}$ & CRS Input-Oriented & Total assets & $\begin{array}{c}\text { Return on Assets and Return } \\
\text { on Investments }\end{array}$ & Hotel Industry in UK & 2007 \\
\hline $\begin{array}{l}\text { Ben Aissa and Goaied } \\
\text { (2016) }\end{array}$ & $\begin{array}{l}\text { CRS Output-Oriented } \\
\text { Then: Bootstrapped } \\
\text { truncated regression, for } \\
\text { evaluating the impact of } \\
\text { external variables on } \\
\text { efficiency }\end{array}$ & $\begin{array}{l}\text { Operating expenses and } \\
\text { Other expenses }\end{array}$ & Turnover & 27 Tunisian Hotels & $2000-2010$ \\
\hline $\begin{array}{l}\text { Cuccia, Guccio and Rizzo } \\
\text { (2016) }\end{array}$ & $\begin{array}{l}2 \text { Output-Oriented models, } \\
\text { applying both CRS and VRS } \\
\text { (4 models in total })\end{array}$ & $\begin{array}{c}\text { Model 1: Total } \\
\text { accomodation capacity } \\
\text { and Total arrivals. } \\
\text { Model 2: Accomodation } \\
\text { capacity in hotel, } \\
\text { Accomodation capacity in } \\
\text { other establishments, } \\
\text { Arrivals in hotel and } \\
\text { Arrivals in other } \\
\text { establishments }\end{array}$ & $\begin{array}{l}\text { Model 1:Total nights slept } \\
\text { Model 2: Nights slept in hotel, } \\
\text { Nights slept in other } \\
\text { establishments }\end{array}$ & $\begin{array}{l}\text { Accomodation industry of Italian } \\
\text { regions }\end{array}$ & $1995-2010$ \\
\hline Huang (2017) & Hybrid DEA & $\begin{array}{c}\text { Number of Manual } \\
\text { Employees, Number of }\end{array}$ & Revenues and Guests & $675 *$ tourist hotel in Taiwan & 2012 \\
\hline
\end{tabular}


Table 2.a: Sample Selection

\begin{tabular}{|c|c|c|c|}
\hline Hotel Star Rating & $\begin{array}{c}\text { Population of } \\
\text { independent } \\
\text { hotels on } \\
\text { Booking.com }\end{array}$ & $\begin{array}{c}\text { Number of } \\
\text { Hotels in the } \\
\text { sample }\end{array}$ & $\begin{array}{c}\text { Total number of } \\
\text { Reviews }\end{array}$ \\
\hline $\begin{array}{c}\text { Five- and four- } \\
\text { Star }\end{array}$ & 167 & 117 & 117.171 \\
\hline $\begin{array}{c}\text { Three- and two- } \\
\text { Star }\end{array}$ & 186 & 141 & 105.885 \\
\hline
\end{tabular}

Table 2.b - Descriptive statistics on online reviews

\begin{tabular}{|c|c|c|}
\hline & Reviews Five- and four- star & Reviews Three- and two- star \\
\hline Min & 117 & 112 \\
\hline Max & 7,316 & 4,144 \\
\hline Mean & 905 & 831 \\
\hline S.D. & 997 & 603 \\
\hline
\end{tabular}

Table 3 - Descriptive statistics for the variables included as inputs and outputs of the DEA model

\begin{tabular}{|c|c|c|c|c|c|c|c|c|c|c|}
\hline & \multicolumn{4}{|c|}{ OUTPUTS } & \multicolumn{6}{|c|}{ INPUTS } \\
\hline & \multicolumn{2}{|c|}{$\begin{array}{c}\text { Revenues } \\
0,00 €\end{array}$} & \multicolumn{2}{|c|}{ Online Rating } & \multicolumn{2}{|c|}{ Rooms } & \multicolumn{2}{|c|}{ Employees } & \multicolumn{2}{|c|}{$\begin{array}{c}\text { Net operating Expenses } \\
0,00 €\end{array}$} \\
\hline & $4-5 *$ & $2-3 *$ & $4-5 *$ & $2-3 *$ & $4-5 *$ & $2-3 *$ & $4-5$ * & $2-3$ * & $4-5^{*}$ & $2-3 *$ \\
\hline Minimum & 412,4 & 302,4 & 6,4 & 6,3 & 15 & 11 & 4 & 3 & 100,1 & 64,8 \\
\hline Maximum & $17.821,4$ & $4.058,8$ & 9,6 & 9,5 & 704 & 200 & 148.0 & 58.0 & $8.714,10$ & $2.054,90$ \\
\hline Mean & $3.255,9$ & $1.032,2$ & 8,3 & 8,1 & 85 & 39,7 & 27,3 & 10,8 & $1.510,00$ & 416 \\
\hline Standard Deviation & $2.772,8$ & 665,7 & 0,6 & 0,7 & 78,5 & 24,9 & 28 & 7,1 & $1.367,80$ & 340,4 \\
\hline
\end{tabular}


Table 4-Magnitude of the variation in rankings after the inclusion of online reviews' valence among the outputs of the DEA model, 2- and 3-star hotels

\begin{tabular}{c|r|r|r|r}
$\begin{array}{c}\text { Variation (positive or } \\
\text { negative) across ranges } \\
\text { in the overall ranking }\end{array}$ & No. & $\begin{array}{c}\text { \% of } \\
\text { inefficient } \\
\text { DMUs }\end{array}$ & Improvers & Receders \\
\hline 0 & 29 & $28.2 \%$ & N.A. & N.A. \\
\hline $1-5$ positions & 37 & $35.9 \%$ & 4 & 33 \\
\hline $6-10$ positions & 25 & $24.3 \%$ & 3 & 22 \\
\hline Over 10 positions & 12 & $11.7 \%$ & 12 & 0 \\
\hline Total & $\mathbf{1 0 3}$ & $\mathbf{1 0 0 . 0 \%}$ & $\mathbf{1 9}$ & $\mathbf{5 5}$ \\
\hline
\end{tabular}

Table 5-The average features of "Improvers", "Receders" and hotels already efficient or keeping the same position in the overall ranking for 2- and 3- stars hotels

\begin{tabular}{l|r|r|r|r|r|r|r}
\multicolumn{1}{c|}{ DMUs } & No. & Revenues & $\begin{array}{c}\text { Net } \\
\text { Operating } \\
\text { Expenses }\end{array}$ & Reviews & $\begin{array}{l}\text { Online } \\
\text { review } \\
\text { valence }\end{array}$ & Rooms & Employees \\
\hline Improvers & 19 & $1,009.1$ & 442.9 & 865.0 & 8.8 & 30.9 & 10.5 \\
\hline Receders & 55 & $1,116.4$ & 427.6 & 812.0 & 8.0 & 41.8 & 11.3 \\
\hline $\begin{array}{l}\text { Hotels maintaining } \\
\text { the same position in } \\
\text { the ranking }\end{array}$ & 29 & 808.1 & 380.2 & 691.5 & 7.8 & 43.6 & 10.6 \\
\hline $\begin{array}{l}\text { Hotels already } \\
\text { efficient with } \\
\begin{array}{l}\text { Revenues as the only } \\
\text { output }\end{array}\end{array} \quad 33$ & $1,135.9$ & 423.1 & 967.2 & 8.2 & 33.4 & 8.9 \\
\hline \multicolumn{1}{c|}{ Total } & $\mathbf{1 3 6}$ & $\mathbf{1 , 0 4 0 . 4}$ & $\mathbf{4 1 4 . 3}$ & $\mathbf{8 3 1 . 4}$ & $\mathbf{8 . 1}$ & $\mathbf{3 8 . 5}$ & $\mathbf{1 0 . 5}$
\end{tabular}

Table 6 - Magnitude of the variation in rankings after the inclusion of online reviews' valence among the outputs of the DEA model, 4- and 5-star hotels

\begin{tabular}{ccccc}
\hline $\begin{array}{c}\text { Variation (positive or } \\
\text { negative) across ranges in } \\
\text { the overall ranking }\end{array}$ & No. & $\begin{array}{c}\text { \% on } \\
\text { inefficient } \\
\text { DMUs }\end{array}$ & Improvers & Receders \\
\hline 0 & 22 & $26.2 \%$ & N.A. & N.A. \\
\hline $1-5$ positions & 35 & $41.7 \%$ & 14 & 17 \\
\hline $6-10$ positions & 19 & $22.6 \%$ & 2 & 0 \\
\hline Over 10 positions & 8 & $9.5 \%$ & 8 & $\mathbf{3 8}$ \\
\hline Total & $\mathbf{8 4}$ & $\mathbf{1 0 0 . 0 \%}$ & $\mathbf{2 4}$ & \\
\hline
\end{tabular}


Table 7 -Average values and features of the "Improvers" vs. "Receders", 4- and 5-star hotels

\begin{tabular}{l|r|r|r|r|r|r|r}
\multicolumn{1}{c|}{ DMUs } & No. & Revenues & $\begin{array}{c}\text { Net } \\
\text { Operating } \\
\text { Expenses }\end{array}$ & Reviews & $\begin{array}{c}\text { Online } \\
\text { review } \\
\text { valence }\end{array}$ & Rooms & Employees \\
\hline Improvers & 24 & $2,407.6$ & $1,186.3$ & 958.9 & 8.7 & 57.8 & 16.8 \\
\hline Receders & 38 & $3,081.4$ & $1,431.4$ & 774.3 & 8.1 & 79.3 & 25.5 \\
\hline $\begin{array}{l}\text { Hotels maintaining the same } \\
\text { position in the ranking }\end{array}$ & 22 & $2,917.1$ & $1,469.1$ & 804.4 & 8.0 & 104.3 & 28.9 \\
\hline $\begin{array}{l}\text { Hotels already efficient with } \\
\text { Revenues as the only output }\end{array}$ & 27 & $4,531.7$ & $1,941.5$ & $1,121.0$ & 8.3 & 101.4 & 37.8 \\
\hline \multicolumn{1}{c}{ Total } & $\mathbf{1 1 1}$ & $\mathbf{3 , 2 5 5 . 9}$ & $\mathbf{1 , 5 1 0 . 0}$ & $\mathbf{9 0 4 . 5}$ & $\mathbf{8 . 3}$ & $\mathbf{8 5 . 0}$ & $\mathbf{2 7 . 3}$
\end{tabular}

Table 8 -Sensitivity analysis: the impact of introducing either the revenues or the online rating among the outputs of the DEA model

\begin{tabular}{|c|c|c|c|c|}
\hline & \multicolumn{2}{|c|}{ 2- and 3-star hotels } & \multicolumn{2}{|c|}{ 4- and 5- star hotels } \\
\hline & $\begin{array}{c}\text { Introducing the } \\
\text { online rating in } \\
\text { the model } \\
\end{array}$ & $\begin{array}{c}\text { Introducing the } \\
\text { Revenues in the } \\
\text { model }\end{array}$ & $\begin{array}{c}\text { Introducing the } \\
\text { online rating in } \\
\text { the model }\end{array}$ & $\begin{array}{c}\text { Introducing the } \\
\text { Revenues in the } \\
\text { model }\end{array}$ \\
\hline $\begin{array}{l}\text { Percentage of inefficient hotels showing an } \\
\text { increase in the efficiency score }\end{array}$ & $19 \%$ & $97 \%$ & $38 \%$ & $99 \%$ \\
\hline Average efficiency score increase & 10.35 & 28.1 & 4.3 & 38.5 \\
\hline $\begin{array}{l}\text { Percentage of inefficient hotels showing a } \\
\text { variation of the ranking higher than } 5 \text { positions }\end{array}$ & $36 \%$ & $93 \%$ & $32 \%$ & $84 \%$ \\
\hline
\end{tabular}


Figure 1-Efficiency scores for 2- and 3-star hotels with/without online reviews' valence among the outputs of the DEA model

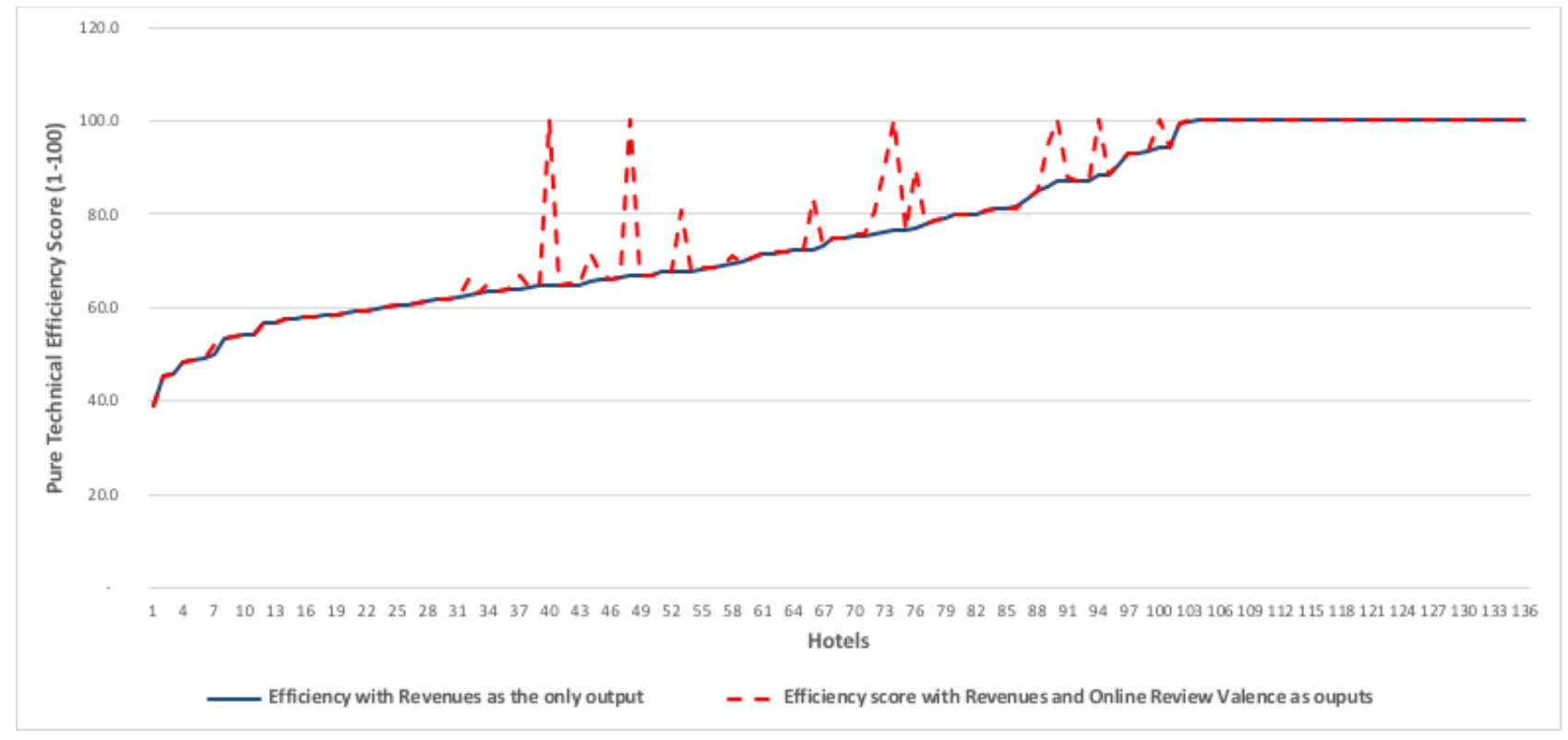

Figure 2 - Efficiency ranking for 2- and 3-star hotels with/without online reviews' valence among the outputs of the DEA model

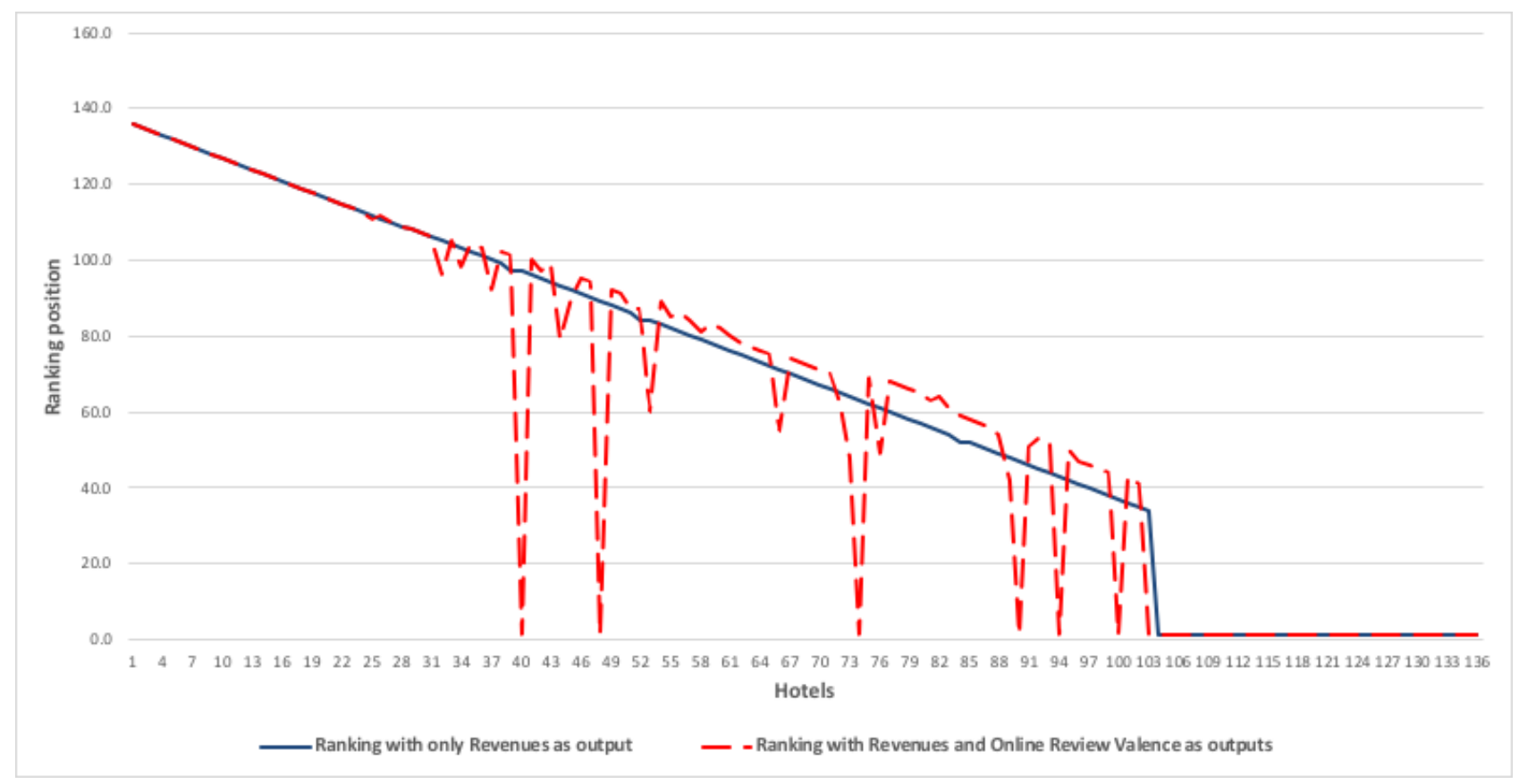


Figure 3-Efficiency scores for 4- and 5-star hotels with/without online reviews' valence among the outputs of the DEA model

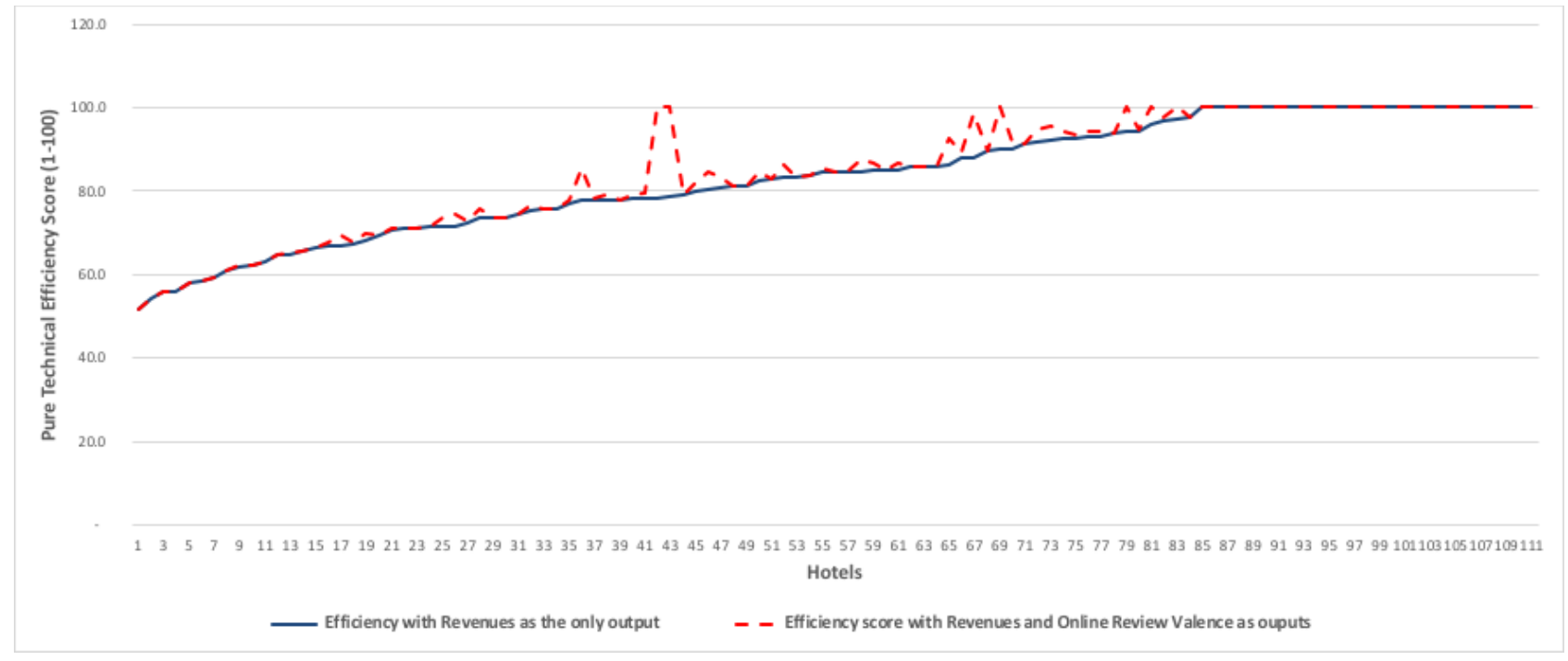

Figure 4 - Efficiency ranking for 4- and 5-star hotels with/without online reviews' valence among the outputs of the DEA model

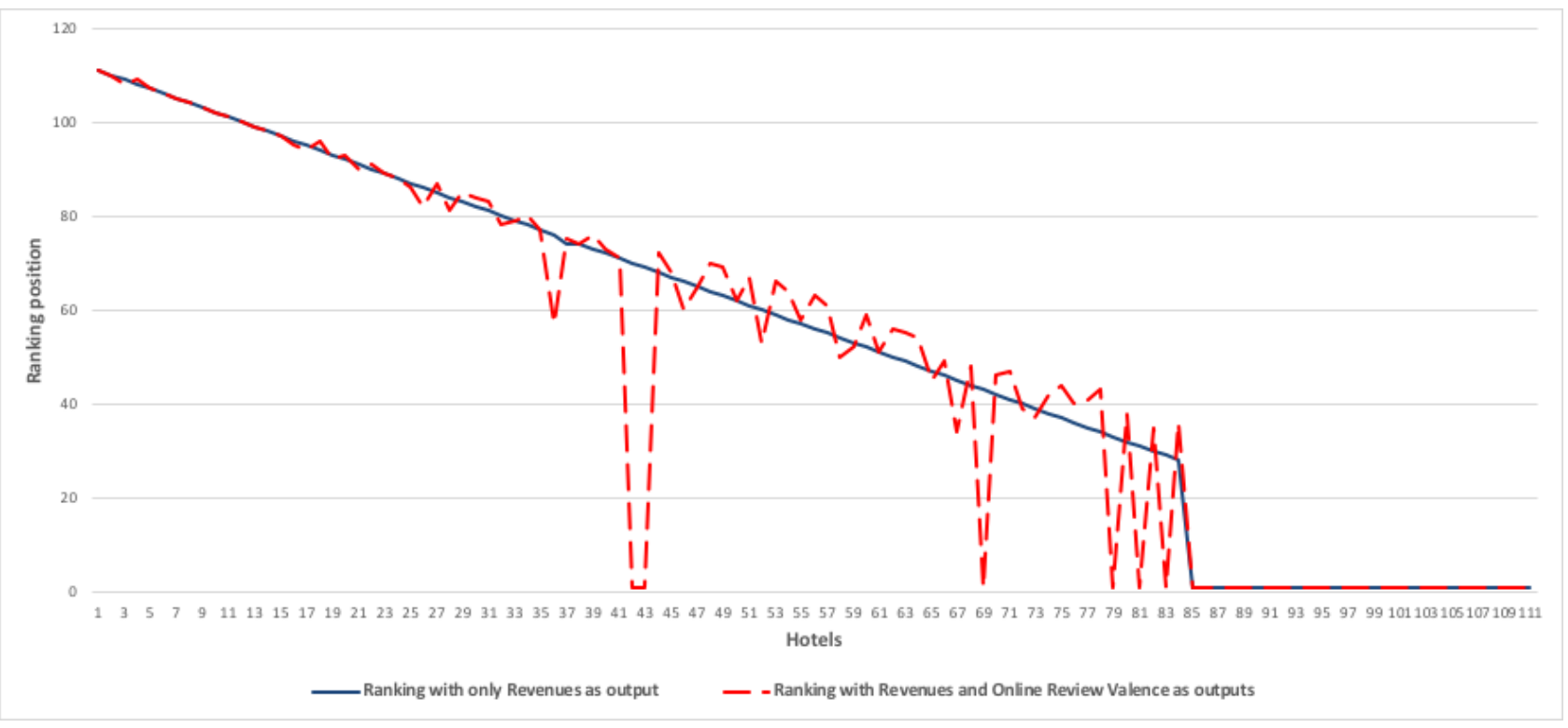

